Research Article

Hans Peter Hahn*

\title{
Commentary Epilogue-Thing Politics and Life-Worlds: On the Dynamics of Conceptual Developments for the Materiality of Society
}

https://doi.org/10.1515/culture-2019-0037

Received March 7, 2019; accepted March 29, 2019

Keywords: networks; thing politics; obstinacy of things; life-world; phenomenology; "excess of things"

\section{Introduction}

The history of the study of material culture is essentially guided by the notion that things function as representatives of society, of the persons involved, and of status differences. "Tell me what you have, and I'll tell you who you are" is the motto of this way of thinking. In this context, stability and traditions are closely associated with material culture, culminating in readings that consider material culture an expression of individual as well as collective identities. In many cases, material objects are also taken as evidence for the continuity of social relations and the expression of stable orientation and values. Informed by the widely acclaimed essays by Thorstein Veblen, Georg Simmel and Pierre Bourdieu, material culture studies propose a strong nexus of social structure, material equipment and the characteristics of certain social groups. Most probably this is the guiding theme in the long tradition of investigating the significance of materiality in societies (Hahn, Materielle Kultur 115ff).

The fundamental metaphor of "material culture as text" aims at the meaning of objects. In this way of thinking, things convey messages; they contain meanings that can be read by individuals or even the majority in a society. Materiality without readable meaning does not figure in social debates, according to the view that has dominated the humanities for centuries. Methodologically, this results in prioritizing the search for the meaning of things, undoubtedly one of the great traditions of Western thought.

However, semiotizing the material may bear some odd fruit, as the example of Christian symbolism clearly shows. The overemphasis on the expressivity of things becomes even less convincing when applied to investigations into the materiality of society as a whole. In this view, neither materiality nor the sensual perception of form, surface and other material qualities turn a thing into a meaningful element within the social order - its significance is merely and exclusively based on pre-established and widely accepted messages.

\section{Networks and Thing Politics}

Undoubtedly, by means of his Actor Network Theory (ANT) Bruno Latour has conceptually contributed to a better understanding of the dynamic entanglements of peopleand things. At the same time and paradoxically, with his question "Where are the missing masses?" he highlighted the idleness of things rather than their

*Corresponding author: Hans Peter Hahn, Institut für Ethnologie, Goethe-Universität Frankfurt a.M., E-mail: hans.hahn@em.uni-frankfurt.de 
agency ("things as actants") (Latour, "Where"). While at first glance the emphasis on "masses" seems to speak more for the persistence of things, with his question Latour has successfully redirected attention to the previously widely underestimated role of materiality in the dynamic transformations of society and everyday life. Krzysztof Pomian's prominent equation of things as "vessels of meaning" is obviously shortcoming in the light of Latour's approach. Thus, in the new framework, things are more than only useful means of conveying messages - rather, they point beyond the notion of the legibility of the material as an exaggerated expectation in itself.

According to Latour, it is the obstinacy of things rather than their meaningful content which constitutes the relevance of the material. Things interact with each other. Likewise, people and things enter into different and often ambiguous processes of interaction, which eventually result in the aforementioned network. This metaphor used by Latour merits a closer look. In its complex and non-regular form, it probably resembles a multiply repaired fisherman's net continuously in need of further repair rather than a spider's web. Its knots all stand for either an object or a human being and are somewhat evenly distributed and connected by lines. The connecting lines refer to shared meanings or actions that connect these objects or people.

Networks are characterized by their extraordinarily flexible structure: lines can be short or long; new connections can be added at any time; even if one or more lines are discontinued, the net as a whole remains intact. Taken together, these aspects of the metaphor contribute to our understanding the importance of the connecting lines, as well as of the people and/or things in their characteristic function as nodes. Fundamentally, Latour is less concerned with the concrete properties (what exactly does a connecting line stand for?) than with the fact that there are significant, although often controversial connections. It is the task of cultural studies scholarship to identify those meaningful connections without which there would be no network in Latour's sense. In this respect, in 1999 Latour proposed with a good reason to understand ANT itself as a method - i.e. as working instructions - rather than a theory or a concept ("On Recalling ANT").

Seen through the lens of ANT, the complex and heterogeneous material environment emerges as an infinite web of numerous superimposed networks. Regardless of whether one takes traffic as a reference point, neighborly relations, daily routines and their associated utensils, in all these cases it is possible to describe the material, technical and economic aspects of our society as highly complex, interrelated and overlapping networks. Man's survival and action depend on so many technical, economic and normative networks that the individual must feel lost in the multitude of interconnected things.

It is an undeniable fact that individuals as much as societies depend on functioning networks, regardless of whether they consciously perceive them or habitually use them. That there lurks a potential danger in such oftentimes unreflected interconnections forms the core of Ian Hodder's argument in his book Entangled: An Archaeology of the Relationships between Humans and Things. Summarily, Latour's and Hodder's achievement lies in sensitizing people to the highly unstable position of man in constantly changing, often unstable networks of things and people and in thus concretely and firmly establishing material culture studies' claim to reassessing the material.

Undoubtedly, Latour aims to unsettle established assumptions and to sensitize his audience for the material aspect of society. And by emphasizing the changeability of networks he takes the logical next step. According to Latour, social change and innovation are regularly based on negotiations about the roles of things. For example, if a society agrees that cars drive too fast, bumpers will be built into the road or other objects (radar measuring devices) used to reduce speed. This may be understood as a provocation, but it is such "policy-making with things" which challenges human behavior (Hahn and Neumann), and, sometimes, results in rather quick changes. If there is a consensus that certain substances are harmful or even poisonous, their use will be banned - as exemplified in the recent history of asbestos (Van Horssen). The dispute about the appropriate place of certain objects (as well as people) in imagined networks constituted a key element for social development. This applies to daily politics, as well as to museum politics or to the political control of the economy through ecological measures. In all cases, the politically intended and enforced change of networks also transforms society. As Latour himself pointed out in his essay "From Realpolitik to Dingpolitik," things in networks are thing politics. 
All the contributions to this special issue explore controversially or even radically differently perceived things with their respective entanglements. Regarding individual contributions through the lens of network theory in the sense of ANT would allow to sketch effortlessly one or more such networks for each case. Each of the articles in this special issue, whether about the images of earthquakes (Leikam) or about "water" (Kluwick), reveals hidden characteristics of things in their insistence on the precise analysis of context. The authors thus convincingly trace connections or plausibly argue for re-evaluation. In this sense, both, earthquake images and memorabilia of the British Navy, serve as examples for "nodes" in the network. The essays not only highlight new connections, but also emphasize their political consequences: Latour's network metaphor proves a viable tool in revealing politics also and intentionally as "thing politics."

\section{Life-Worlds and the Surprise of Immediate Encounter}

By the same token, the objects portrayed in this special issue also stand for a critical examination of other life-worlds, some of which are distant or past. Therefore, one can say that these objects offer unique insights into life-worlds otherwise unreachable. This argument is supported by the conceptual framework of the life-world, which connects the perception of materiality with the individual's social and cultural spheres. The term was originally developed by Husserl (1936) to highlight the diversity of individual perceptions, interpretations and valuations co-existing within a society. It has since become a significant tool in understanding why some things appear to be powerful and meaningful, while others do not.

Ulrich Claesges reminds us that Husserl used the term in the 1930s in order to confront excessive and unacceptable objectification. Insofar as life-world prioritizes the sensory perception of technical and other material things, it directs attention to impression and experience. When the material confronts humans in their role as perceivers, it creates various impressions. Encounters convey experiences that gradually sediment into an image of the world. The only framing envisioned by the concept of life-world is the subjective horizon of perception.

There is hardly a thinker better equipped to properly describe the flow of perceptions than Maurice Merleau-Ponty. In full coherence with Husserl's idea of phenomenology, his explanations originate in the rejection of any notion claiming an "objective evaluation" of a material object. According to Merleau-Ponty, both perception and evaluation arise only at the moment of encounter. Perception is not immanent to the object but is generated by its presence. All things possess multiple features, only a few of which become relevant to the viewer. In his opus magnum "Phenomenology of Perception" (1945), Merleau-Ponty vividly describes how completely subjective perceptions can assume a motivating force, even though they do not emanate from an object or another stimulus of the environment (as for example the so-called phantom pain).

Accordingly, the presence of a material object equals a specific perception - often habitual, perhaps even unconscious, but occasionally also surprising or even provocative. Lorraine Daston's idea of "obdurate objecthood" refers precisely to the inherently unfinished, oftentimes paradoxical character of perception at the moment of encounter (Things that Talk). Therefore, we may appropriately speak of the "obstinacy of things" - not to imply a quality of "being obstinate" but rather to propose that perception assumes the unexpected properties of the object perceived owing to this object's material constancy

(Hahn, Vom Eigensinn der Dinge). Bernhard Waldenfels underscores the embedded and specific nature of such immediate experience of things ("Die Mitwirkung der Dinge in der Erfahrung"). Whether we regard something as relevant or negligible also depends on our previous experience, sensitivity and not least on the composition of our perceptual horizons.

The presence of material things always holds surprises, for the moment of perception is an event with an unpredictable outcome. This corresponds to Heidegger's notion of thing-ness (1954): Things present themselves as a totality of properties which is never fully foreseeable, yet already pre-designed in their material continuity (Olsen, "Keeping Things at Arm's Length"). Hans-Ulrich Gumbrecht considers the presence of the material as fundamental to the open character of agency (Präsenz). Ultimately, we cannot predict how an object will work, whether it will arouse esteem or disgust, whether it will draw attention to 
itself at all, or whether it will remain marginal to consciousness. Fundamental to the phenomenological modelling of the encounter with an object is the excess of potential and actual perceptions that flood the observer. Processes of selection and evaluation of such sensual experiences vary individually and in kind just as their embedding in subjective life-worlds.

Therefore, describing the potential of emitting an inexhaustible series of properties as the excess of things constitutes a viable approach, pursued by Nikolina Hatton with reference to Bill Brown in her contribution to this issue. It coincides with Klaus Scherpe's explanation of the "excess of things" as a threat to "ordered" (and at the same time scientific) perception ("Die Ordnung der Dinge als Exzeß").

A life-world is shaped by an infinite chain of successive impressions. Much of it repeats itself and becomes habitual, which effects the orientational power of things. A chair invites sitting on it; the laid table is a prompt for sharing a meal. However, I concur with François Sigaut in emphasizing that such affordance never exhausts the possibilities of confronting an object. According to Sigaut, a knife is not only for cutting, and, besides sitting on it, a chair can also be used as a ladder ("Un couteau ne sert pas à couper, mais en coupant").

The life-world concept is special in that it allows to discriminate the various perceptions with regard to different subject positions and perspectivize them with regard to the viewer. Several contributions to this special issue uncover new approaches concealed in things. With her contribution on memorabilia of the British Navy, Ulrike Zimmermann demonstrates how relevance changes over time. The same accounts for the controversial perspectives of the Mississippi River unfolded in Bärbel Tischleder's contribution: Properties turn out to be deceptive; contrasting characterizations exist in juxtaposition. The strength of such approaches rests in their openness towards re-evaluation as much as in the insight that it is the process of evaluation that constitutes the specificity of life-worlds. Therefore, life-worlds always must be considered as plural, and we may take literary transformations of perception as a cultural space for the finest nuances as well as for the juxtaposition of different perspectives.

\section{Life-Worlds and Networks: An Unequal Couple}

The point of my conceptual sketch is to argue that the notion of life-worlds creates "uneven worlds." This concept helps in depicting the material environment as a cosmos of infinite properties, in some cases made relevant by perception, in other cases neglected or even ignored. Given sufficient attention to embeddedness and subjective perspectivizing, all things qualify for sensory impressions, and every single material object may eventually provoke contradiction or irritation.

While life-worlds suggest an uneven universe made up of an infinite number of singular, luminous or only blurry entities, networks make for quite a different case. No object exists in and of itself. Its relevance results from the connection with other material things. The basic metaphor of the network is flexible; it constantly changes its structure but still remains a network. For some critics, this is reason enough to blame Latour for an implicit conceptual proximity to monism in its Leibnitzian articulation, which they consider as a return to philosophical concepts of the early $19^{\text {th }}$ century (Epstein, The Ant Trap).

As a concept to account for human-thing relations, networks produce a "flat world" in which the decisive quality is "being networked". The properties of things translate into relationships that could also be understood as "interactions with people or other things." There is no entity outside of such relationships. At the same time, networks produce an economy of relations: Nodes are accorded centrality within the network based on their number of connecting lines, which corresponds to the frequency of perceived relations. Outside of such relatedness, no quality attains relevance. With this approach, Latour not only paved the way for posthumanism but has elaborated on it with reference to Gaia theory ("Waiting for Gaia"). A world held together by the weaving of interdependencies no longer privileges humans over any other object (Hahn, "Material Culture" 11). The universe is a network the nodes of which are humans, animals, plants, things. Thing politics consists of the option to influence the future of the planet by changing the structure of the network. 
The "flat world" of networks faces the "uneven landscape" of life-worlds. Both are currently convincing and widely used approaches to material culture. They are clearly distinguishable from each other and offer themselves as alternatives. Even if the lines of demarcation may occasionally appear blurry, we must remain clear that they offer fundamentally different, in fact alternative approaches to material culture. In dealing with things, both approaches represent viable routes of access. The contributions to this issue contain both approaches, albeit to varying intensities. This epilogue therefore aims at encouraging the recognition and realization of the tension between these approaches, especially with regard to reflecting on their methodological implications.

Both the network as a metaphor of thing politics or life-world as the ensemble of subjective sensory perception are powerful tools in elucidating human-thing relations. Preference for either will necessarily depend firstly on the kind and amount of available information. Furthermore, it is a matter of modelling the world: Do we derive insight from perception in its infinite variety or from the logic of necessary relationships of people and things and things with things? At this point in the debate, this question must remain open.

Acknowledgement: For their support in translating the epilogue my heartfelt thanks go to Ingrid Gessner and Juliane Schwarz-Bierschenk as well as for inspiring comments on earlier versions of this essay.

\section{Works Cited}

Claesges, Ulrich. "Zweideutigkeiten in Husserls Lebenswelt-Begriff." Perspektiven transzendentalphänomenologischer Forschung: Für Ludwig Landgrebe zum 70. Geburtstag von seinen Kölner Schülern, Phaenomenologica 49, edited by Ulrich Claesges and Klaus Held, Martinus Nijhoff, 1972, pp. 85-101.

Daston, Lorraine. “Introduction.” Things that Talk: Object Lessons from Art and Science, edited by Lorraine Daston, Zone Books, 2004, pp. 9-24.

Epstein, Brian. The Ant Trap: Rebuilding the Foundations of the Social Sciences. Oxford University Press, 2015.

Gumbrecht, Hans U. Präsenz. Suhrkamp, 2012.

Hahn, Hans P. Materielle Kultur: Eine Einführung. Reimer, 2005.

Hahn, Hans P., editor. Vom Eigensinn der Dinge: Für eine neue Perspektive auf die Welt des Materiellen. Neofelis, 2015.

Hahn, Hans P. “Material Culture.” International Encyclopaedia of Anthropology, edited by Hilary Callan, Wiley Blackwell, 2018, pp. 1-15.

Hahn, Hans P. and Friedemann Neumann, editors. Dinge als Herausforderung: Kontexte, Umgangsweisen und Umwertungen von Objekten. Transcript, 2018.

Heidegger, Martin. “Das Ding.” Bremer und Freiburger Vorträge. (= Heidegger Gesamtausgabe (HGA), Band 79), edited by Petra Jaeger, Klostermann, 1994, pp. 5-21.

Hodder, Ian. Entangled: An Archaeology of the Relationships between Humans and Things. Blackwell, 2012.

Husserl, Edmund. Die Krisis der europäischen Wissenschaften und die transzendentale Phänomenologie: Eine Einleitung in die phänomenologische Philosophie. Philosophia 1, 1936, pp. 77-176.

Latour, Bruno. "Where Are the Missing Masses? The Sociology of a Few Mundane Artifacts." Shaping Technology / Building Society: Studies in Sociotechnical Change, edited by Wiebe E. Bijker and John Law, MIT Press, 1992, pp. 225-258.

----.. "On Recalling ANT.” Actor Network Theory and After, edited by John Law and John Hassard, Blackwell, 1999, pp. 15-25.

----.. "From Realpolitik to Dingpolitik or How to Make Things Public." Making Things Public: Atmospheres of Democracy, edited by Bruno Latour and Peter Weibel, MIT Press, 2005, pp. 14-45.

----.. "Waiting for Gaia: Composing the Common World Through Art and Politics." What is Cosmopolitical Design? Design, Nature and the Built Environment, edited by Albena Yaneva and Alejandro Zaera-Polo, Ashgate, 2015, pp. 21-33.

Merleau-Ponty, Maurice. Phénoménologie de la perception, Gallimard, 1945.

Olsen, Bjørnar. “Keeping Things at Arm's Length: A Genealogy of Asymmetry.” World Archaeology, vol. 39, no. 4 (Dec. 2007): 579-588.

Scherpe, Klaus R. “Die Ordnung der Dinge als Exzeß: Überlegungen zu einer Poetik der Beschreibung in ethnographischen Texten.” Das Fremde: Reiseerfahrungen, Schreibformen und kulturelles Wissen (= Zeitschrift für Germanistik, N.F., Beiheft; 2), edited by Alexander Honold and Klaus R. Scherpe, Peter Lang, 1999, pp. 13-44.

Sigaut, François. "Un couteau ne sert pas à couper, mais en coupant: Structure, fonctionnement et fonction dans l'analyse des objets." 25 ans d'études technologiques en préhistoire: Bilan et perspectives, edited by C. Perles, Editions ACDPA, 1991, pp. 22-34.

Van Horssen, Jessica. A Town Called Asbestos: Environmental Contamination, Health, and Resilience in a Resource Community. UBC, 2016.

Waldenfels, Bernhard. "Die Mitwirkung der Dinge in der Erfahrung." Vom Eigensinn der Dinge: Für eine neue Perspektive auf die Welt des Materiellen, edited by Hans-Peter Hahn, Neofelis, 2015, pp. 57-79. 